\title{
Antecedents and Outcomes of Brand Management from the Perspective of Resource Based View (RBV) Theory
}

\author{
Imelda Albert Gisip \\ Universiti Teknologi MARA \\ Email: imeldag@sabah.uitm.edu.my \\ Amran Harun \\ Universiti Malaysia Sabah
}

\section{Doi:10.5901/mjss.2013.v4n10p432}

\begin{abstract}
Brand management requires greater emphasis on internal factors to increase brand performance. A model of antecedents and outcomes of brand management is developed in this study based on the Resource Based View (RBV) Theory. Top management emphasis on brand, corporate supportive resources and market orientation are identified as crucial internal factors or antecedents for success of brand management. Apart from that, the brand management measurement are expanded in this study with the introduction of three new marketing constructs namely marketing capabilities, innovation and brand orientation as new dimensions in brand management which currently comprised of management related constructs. This study also contributes in the brand management of small and medium enterprise (SMEs) literature as previous studies mainly focused on the brand management for multinational companies or large organizations. One important issue of SMEs is the "internal" brand management which is currently under-researched even though it is critical in brand building and management. Therefore, this research aims to highlight the antecedents and outcomes of brand management in Malaysians' SMEs based on $R B V$ theory. A comprehensive literature review was done and a conceptual model is proposed in this literature review.
\end{abstract}

Keywords: Brand management, SMEs, Resource Based View Theory

\section{Introduction}

An area of increasing importance to marketers today is brand management particularly as firms attempt to communicate the ever complex and intangible messages as part of brand management strategies (Davis, 2000; Goodchild \& Callow, 2001). Possessing a strong brand allows SMEs companies to differentiate their products or services from the competitors, build customer loyalty and confidence, command a premium price over the competitors, employ as well as greater control over brand promotion and distribution; all while impacting the business valuation (Holverson \& Revaz, 2006; Pass, Lowes, Pendleton \& Chadwick 1995). Nevertheless, the literature related to effects of brand management to brand performance in SMEs context has yet to be fully explored. The main aim of proposed research is to determine the antecedents and outcomes of brand management in SMEs context by examining internal factors that contributes to the success of brand management based on RBV theory. In addition, the study also aims to highlight the importance of brand management among SMEs.

\section{Theoretical Background - Resource Based View (RBV) Theory}

The resource based view (RBV) theory views a firm as a bundle of resources and capabilities (Wernerfelt, 1984). Resources are categorized as tangible (physical or financial) or intangible (i.e., firm's reputation, skills and experiences, organizational procedures, employee's knowledge, brand name). In contrast, capabilities are referred to the ability of firm to capitalize its resource "to affect a desired end" (Amit and Schoemaker, 1993) or capacity of a firm to combine different resources by means of organizational processes in order to produce desired results (Prahalad \& Hamel, 1990; Grant, 1996). RBV framework has been broadly used in the marketing literature specifically to understand the performance of inter-organizational relationship (Palmatier, Dant, \& Grewal, 2007), to analyze the relations of marketing and other functional capabilities and their consequence on performance (Song, Droge, Hanvanich \& Calantone, 2005; Song, Nason 
\& Benedetto, 2008) and to examine firm's performance (Dutta, Narasimhan, \& Surendra, 1999; Liebermann \& Dhawan, 2005). However, even though substantial works has been published about brand management, an extensive literature reveals issues related to internal factors contributing to the success of brand management based on RBV have yet to be fully covered. This "internal" brand management is crucial in brand building and management as without supportive internal processes no brand objectives can be really accomplished (Chen, Lam, \& Zou, 2011). In spite of the diverse perspectives adopted in previous studies, brand management in this present study will involve three sets of variables namely antecedents, brand management, and performance outcomes. The work by Chen et al (2011) and Lee, Park, Baek, \& Lee (2008) integrative model are used to develop the present study's framework.

\section{Conceptual Model and Research Hypotheses}

The conceptual model that guides the present empirical effort is presented in Figure 1. The antecedents of brand management, previously comprised of two internal organizational factors in Chen's model -top management emphasis and corporate supportive resources- are expanded by examining an additional organizational factor - namely, market orientation and a thorough review of the mainstream marketing literature shown that the work of Lee et al.'s (2008) provides a comprehensive study of market orientation in the brand management context, as apparent by its extensive use in consequent brand management and brand performance studies. The brand management in this study is conceptualized based on the work of Lee et al (2008). Brand management is defined as a set of any systems, organizational culture or structure of a firm supporting activities of brand building. In this study, two of the building activities proposed by Lee et al (2008) related to brand such as brand-related organization and culture and brand knowledge will be adopted. In addition three new constructs namely: marketing capabilities, innovation and brand orientation will be conceptualized as new dimensions in brand management and will be further elaborated in the next sections.

Figure 5. Conceptual Framework of Antecedents and Outcomes of Brand Management

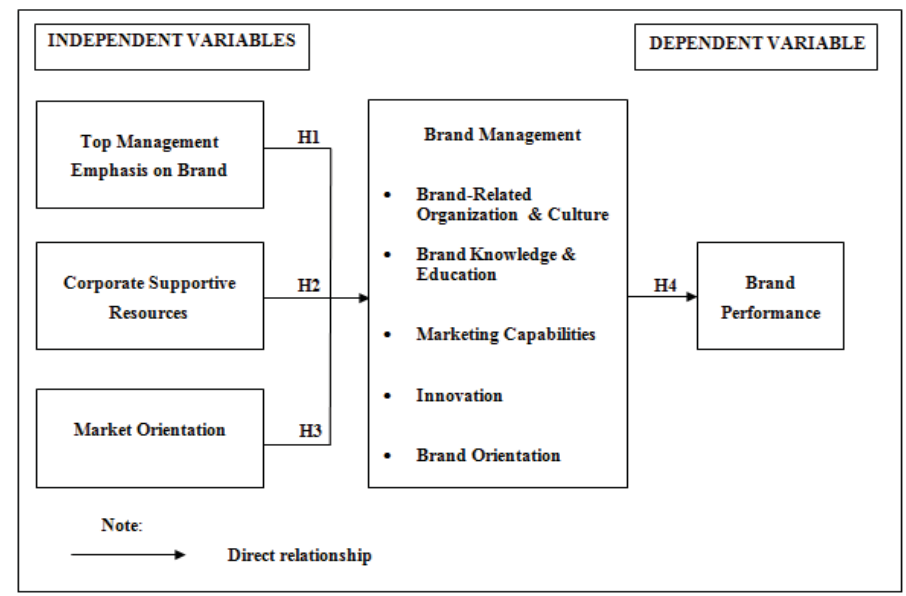

\subsection{Top Management Emphasis on Brand and Brand Management}

Top management emphasis on brand refers to top managers' attitude toward brand management, comprising the strategic position of brand building, understanding about types of brand image to build, and the efforts dedicated to development of brand (Jaworski and Kohli, 1993). Past studies have revealed that leaders or top management have important effect in influencing the values and orientations of the whole company (Hambrick \& Mason, 1984; Jaworski et al., 1993; Zhou, Gao, Yang and Zhou, 2005). According to Awamleh \& Gardner (1999) a vital element for business performance is top managers who inspire employees to dedicate themselves to brand-building activities more assertively and diligently by communicating a consistent and clear message of brand management. Besides that, Urde (1999) suggests top managers to support brand management by ensuring the brand team has better coordination from other 
departments as well as ample support. This is specifically critical in the case of brand management whereby top management emphasis play significant roles in the internal brand building process which then contributes to enhanced business performance. Top management emphasis on brand is a key resource in influencing the success of brand management in a sense that it provides support to the brand-related activities (Chen et al., 2011; Richardo, 2001; Wong \& Merrilees, 2005). Therefore, it is hypothesized that:

Hypothesis 1: Top management emphasis on brand will have a positive effect on the five-dimensional brand management in SME (brand-related organization and culture, brand knowledge and education, marketing capabilities, innovation and brand orientation).

\subsection{Corporate Supportive Resources and Brand Management}

Corporate supportive resources describes the willingness of the firm to assign more resources to the brand and tangible resources assigned to the brand (Harrison, Hall, \& Nargundkar, 1993; Wernerfelt, 1984) specifically on tangible resources (for example financial resource) that would be available for development of a brand. Management should realize the required resources and capabilities (e.g financial resource networking alliances and human resources) as these are critical to develop for firm's success and to increase performance and differential advantage (Chen et al., 2011; J. Wicklund, 2009; Ndubisi, 2012; Sarah \& Arokiasamy, 2009; Wernerfelt, 1984). Chen et. al (2011) further argues the importance of corporate supportive resources that in planning a brand strategy, several activities need to be conducted namely recruitment of employees and marketing research. During implementation, constant investments in the form of financial resources and human capitals are needed in almost all activities such as advertising, promotion and distribution. In particular, without sufficient resources, such activities would be impossible to be realised. Therefore, it is hypothesized that:

Hypothesis 2: Corporate supportive resources will have a positive effect on the five-dimensional brand management in SME (brand-related organization and culture, brand knowledge and education, marketing capabilities, innovation and brand orientation).

\subsection{Market Orientation and Brand Management}

Market orientation is an organization culture and is incorporated in the inter-functional coordination within an organization as a critical resource for brand management (Narver and Slater, 1990; Slater \& Narver, 1994, 1995). Firms that pursue market orientation strive to improve customers' needs, react fast to competitors' tactics and inter-functional coordination are more likely to enjoy strong brands due to a close relation with customer performance (Narver and Slater, 1990). By reacting and pursuing to preferences and needs of customer, market-oriented firms satisfy customers better than competitors and attain greater financial performance (Greenley, 1995; Jaworski \& Kohli, 1993). Brand management has also been found to have a significant impact on brand performance if influenced by market orientation, due to tracking and reacting to customer needs and preferences, market-oriented firms are able to satisfy customers and reach superior financial performance (Lee et al 2008). Therefore, it is hypothesized that:

Hypothesis 3: Market orientation will have a positive effect on the five-dimensional brand management in SME (brand-related organization and culture, brand knowledge and education, marketing capabilities, innovation and brand orientation).

\subsection{Brand Management and Brand Performance}

Brand management is related to a set of any systems, organizational culture or structure of a firm which supports brand building activities (Lee et al. 2011). Brand management is the degree of infrastructure building activities related to brand such as brand-related organization and culture, brand knowledge and education (Davis \& Dunn, 2002; Low \& Fullerton, 1994; Vanauken, 2002). Three new constructs are incorporated as new dimensions in brand management namely marketing capabilities, innovation and brand orientation which will be elaborated in the next sections.

\subsubsection{Brand-Related Organization and Culture and Brand Performance}

Brand-related organization and culture refers to top management interest on brand, power of brand manager, brand manager system, employee's branding motivation and brand information sharing by Lee et al., (2008). The positive 
relationship of brand-related organization and culture and brand performance is expected based on the observation of companies in which branding processes flows in all areas such as Procter \& Gamble, Sony and Nike (Noble, Sinha \& Kumar, 2002). Additionally, the widespread interest to branding activities is observed in a broad variety of academic disciplines including general management (e.g., Drucker, 2002), marketing (e.g., Aaker, 2004; Keller, 2003) and also in practical fields (Low \& Fullerton, 1994) show. Therefore, it is hypothesized that:

Hypothesis 4(a): There is significant relationship between brand-related organization and culture and brand performance in SMEs.

\subsubsection{Brand-Related Knowledge and Education and Brand Performance}

Brand knowledge and education refers to brand education for managers, brand education for employees, employee's effort to understand branding and workshop or training (Lee et al., 2008). Using RBV of the firm as theoretical background, Olavarrieta \& Friedmann (1999) studied the role of knowledge-related resources as key antecedents of the continuous creation of competitive advantages to describe superior business performance. Studies have highlighted that progress of new insights or knowledge in the organization can be an essential determining factor of superior business performance and sustainable competitive advantages (Fiol and Lyles, 1985; Levitt and March, 1988; Sinkula, 1994). Knowledge of reactions to the industry structure and the competitive strength faced by a firm subsequently affect the firm's strategic decisions (Weerawardena, O'Cass, 2004). Firms struggling to attain higher brand performance ought to do a joint effort to understand its customers and competitor actions which in turn allows them to incorporate its marketing tools to achieve the required market effectively (Cass et al., 2004). Knowledge-based resources (related to utilization of opportunities and discovery) are found to be positively related to firm performance and knowledge of the competitive intensity faced by a firm and reactions to the industry structure subsequently affect firm's strategic decisions (Wiklund and Shepherd, 2003; Cass, Weerawardena, \& Julian, 2004). Therefore, it is hypothesized that:

Hypothesis 4(b): There is significant relationship between brand-related knowledge and education and brand performance in SMEs.

\subsubsection{Marketing Capabilities and Brand Performance}

Marketing capabilities refers to complex processes which comprised of organizational resources and market knowledge to produce added value (Vijande, Perez, Gutierrez, 2012). Having superior marketing capability leads to firms' superior performance (Liem Ngo and Aron O'Cass, (1998); strengthen the value of products and services (e.g. brand equity) (Aaker,1996) and allows firms to achieve sustained competitive advantage (Cooper \& Kleinschmidt, 1987; Vorhies \& Morgan, 2005; Woodside, Sullivan \& Trappey 1999); Weerawardena et al., 2004). Kotabe, Srinivasan, and Aulakh (2002) suggest that the firm's ability to build successful brands and distinguish products and services from competitors reflect the firm's marketing capability. A broad use of RBV framework in the literature regarding the analysis of firm performance (Dutta, Narasimhan and Surendra, 1999; Liebermann and Dhawan, 2005) to investigate the impact of marketing capabilities on performance (Song et al., 2007; Song, Droge, Hanvanich, \& Calantone, 2005; Song, Nason, \& Benedetto, 2008) imply that a significant relationship exists between capabilities and performance. Therefore, it is hypothesized that: Hypothesis 4(c): There is significant relationship between marketing capabilities and brand performance in SMEs.

\subsubsection{Innovation and Brand Performance}

Innovation relates to the practical ideas application to effectively utilize the capabilities of a firm and it goes beyond the products and service level to include modification in process and system (Cram 1996; Wong \& Merrilees, 2008.). It signifies the firm's innovation level in relations to its marketing management approach. For example, Gatignon and Xuereb (1997) argue that to obtain and develop sophisticated technologies in the new products development (brands), the key characteristics of R\&D orientation are innovation-oriented organisations and pro-activeness. Deshpande and Zaltman (1993) suggested that innovative culture contributes to performance hence innovation is needed for organizations to be successful. O'Cass and Ngo (2007) concurred with this view by suggesting that innovative culture empowers the firm to generate opportunities through guiding the market and also enhance its brand performance. Empirical evidence also revealed that in the context of SMEs, innovation was a positive determinant of brand performance at the brand level (Weerawardena, O'Cass \& Julian, 2006). The possession of market-sensing skills and market-oriented culture are important resources to cultivate and promote imitation capabilities and innovativeness in an 
organization and can be considered as keys for the success and survival of the firm (Olavarrieta \& Friedmann, 1999). Therefore, it is hypothesized that:

Hypothesis 4(d): There is significant relationship between innovation and brand performance in SMEs.

\subsubsection{Brand Orientation and Brand Performance}

Brand orientation refers to mindset that directs a firm in terms of strategic marketing planning and promises that the brand will be known, favoured and featured in the marketing strategy and for a firm to build up its competitive advantages in markets it should be the first step (Wong et al., 2008). Generally, brand orientation could improve the marketing performance in various ways including building strong brand awareness and enhancing firm's reputation (Calderon et al. 1997). It could even nurture brand loyalty that leads to certain marketing advantages such as new customers, greater trade leverage and lower marketing costs. As supported by Herbig and Milewicz (1997) brand orientation could build brand awareness and loyalty which can reduce price premium and marketing cost, where brand loyalty can bring to a firm include positive word of mouth and superior resistance among loyal consumers to competitors' strategies (Calderon, H., Cervera, A., Molla, 1997; Dick and Basu, 1994). These findings suggest that with being more brand-oriented in brandrelated activities, brand performance can be improved. Therefore, it is hypothesized that:

Hypotheses 4 (e): There is significant relationship between brand orientation and brand performance in SMEs.

\subsubsection{Brand Management as Mediating Factor}

Although the firm has required capabilities to acquire related customer needs and behaviour information from the marketplace, it may lack the processes and systems to incorporate this information into the firm for product-related decision making (Roach, 2011). Therefore, market-oriented firms who lack brand management capabilities may be very effective at gathering external information (for example in SMEs founder is normally the primary information gatherer), but unable to sufficiently transmit this knowledge to the firm. In contrast, the firm may be functionally very strong, but lack the ability to disseminate and share relevant information across functional boundaries for decision making purpose. Therefore, brand management goes beyond mere market-oriented culture and behaviour by enhancing (or mediating) its impact on brand performance. This study thus postulates that brand management may be one of the missing mediation effects between the internal resources and brand performance as highlighted in several studies (Lee et al, 2008).

Hypotheses 5 (a): Brand Management Mediates the Relationship between Top Management Emphasis on Brand and Brand Performance in SMEs.

Hypotheses 5 (b): Brand Management Mediates the Relationship between Corporate Supportive Resources and Brand Performance in SMEs.

Hypotheses 5 (b): Brand Management Mediates the Relationship between Market Orientation and Brand Performance in SMEs.

\section{Concluding Remarks}

The model addresses the gaps in the literature by identifying the antecedents of brand management based on the RBV theory. Top management emphasis on brand, corporate supportive resources and market orientation are identified as crucial internal factors or antecedents for success of brand management. Apart from that, as recommended by Lee et al., (2008), the brand management measurement are expanded in this study with the introduction of three new marketing constructs namely marketing capabilities, innovation and brand orientation as new dimensions in brand management which currently comprised of management related constructs. In summary, a conceptual model of brand management has been proposed in this literature review which is governed by RBV theory. This study also contributes in the brand management literature as previous studies mainly focused on the brand management for multinational companies or large organizations, while studies in the SMEs context have yet to be fully covered.

The authors have recently embarked on empirical research to test the model developed in this study and the internal factors believed to influence brand management and its outcomes. Findings will be reported in future publications. 


\section{References}

Aaker, D. (2004). Brand portfolio strategy. New York: Free Press.

Amit, R. \& Schoemaker, P. (1993): "Strategic assets and organizational rent", Strategic Management Journal, Vol. 14, pp. 33-46.

Awamleh, R., \& Gardner, W. L. (1999). Perceptions of leader charisma and effectiveness: The effects of vision content, delivery, and organizational performance. Leadership Quarterly, 10(3), 345-373.

Calderon, H., Cervera, A., Molla, A. (1997). Brand Assessment: a Key Element of Marke- ting Strategy. Journal of Product \& Brand Management ., 6((5)), 293-304.

Cass, A. O., Weerawardena, J., \& Julian, C. C. (2004). Industry structure in marketing strategy and brand performance.

Cram, T. (1996), "A manager's guide to innovation", Journal of Product \& Brand Management, Vol. 5 No. 5, pp. 15-17

Chen, X., Lam, L. W., \& Zou, H. (2011). Antecedents and Performance Consequences of Integrated Brand Management in China: An Exploratory Study. Journal of Global Marketing, 24(2), 167-180.

Cooper, R.G., Kleinschmidt, J.K., 1987. New products: what separates winners from losers?. Journal of Product Innovation Management 4 (3), 169-184.

Davis, S.M. (2000). Brand Asset Management: Driving Profitable Growth through Your Brands. Jossey-Bass, San Francisco.

Davis, S. M., \& Dunn, M. (2002). Building brand-driven business. San Francisco, CA: Jossey-Bass.

Dick, A.S. and Basu, K. (1994), "Customer loyalty: toward an integrated conceptual framework", Journal of the Academy of Marketing Science, pp. 99-113.

Dutta, S., Narashiman, O., \& Surendra, R. (1999). Success in high technology markets: Is marketing capability critical? Marketing Science, 18(4), 547-568.

Drucker, P. F. (2002). Managing in the next society. New York, NY: St. Martin's Press.

Fiol Marlene, Lyles Marjorie A. Organizational learning. Acad Manage Rev 1985;10:803-13.

Gatignon, H. ve Xuereb, J.M., 1997, 'Strategic Orientation Of The Firm And New Product Performance', Journal of Marketing Research, 34,1, pp. $77-90$.

Grant RM. 1996. Prospering in dynamically-competitive environments: organizational capability as knowledge integration. Organization Science 7(4): 375-387

Greenley, G.E., 1995, 'Market Orientation and Company Performance: Empirical Evidence from UK Companies', British Journal of Management, 6, pp. 1-13.

Goodchild, J., \& Callow, C. (2001). Brands: Visions \& Values. John Wiley \& Sons, New York, NY.

Hambrick, D.C., Mason, P.A., 1984. Upper echelons-the organization as a reflectionof its top managers. Academy of Management Review 9 (2), 193-206

Harrison, J. S., Hall, E. H., Jr., \& Nargundkar, R. (1993). Resource allocation as an outcropping of strategic con- sistency: Performance implications. Academy of Man- agement Journal, 36(5), 1026-1051.

Herbig, P. and Milewicz, J. (1997), "The relationship of reputation and credibility to brand success", Pricing Strategy and Practice, Vol. 5 No. 1, pp. 25-9.

Holverson, S., \& Revaz, F. (2006). Perceptions of European independent hoteliers: hard and soft branding choices. International Journal of Contemporary Hospitality Management, 18(5), 398-413.

J. Wicklund, H. Patzelt and D. Shepherd, "Building an Integrated Model of Small Business Growth," Small Busi- ness Economics, Vol. 32, No. 4, 2009, pp. 351-374.

Jaworski, B.J. and Kohli, A.K. (1993), "Market orientation: antecedents and consequences", Journal of Marketing, Vol. 57, July, pp. 5370.

Keller, K. L. (2003). Strategic brand management, 2nd edition Englewood Cliff, NJ: Prentice Hall.

Kotabe, M., Srinivasan, S.S., Aulakh, P.S., 2002. Multinationality and firm performance: the moderating role of R\&D and marketing capabilities. Journal of International Business Studies 33 (1), 79-97.

Lee, J., Park, S. Y., Baek, I., \& Lee, C.-S. (2008). The impact of the brand management system on brand performance in B-B and B-C environments. Industrial Marketing Management, 37(7), 848-855.

Levitt B, March James G. Organizational learning. Annu Rev Sociology 1988;14:319-38 [August].

Liem Ngo and Aron O'Cass. (1998). Explaining Brand Performance Differentials between Firms via Innovation and Marketing Liem Ngo and Aron O'Cass, The University of Newcastle, 1-8.

Liebermann, M. B.,\& Dhawan, R. (2005). Assessing the resource base of Japanese and US auto producers: A stochastic frontier function production approach. Management Science, 51(7), 1060-1075.

Low, G. S., \& Fullerton, R. A. (1994). Brands, brand management, and the brand manager system: A critical-historical evaluation. Journal of Marketing Research, 31(2), 173-190.

Moorman, Christine, Rohit Deshpande and Gerald Zaltman (1993), "Factors Affecting Trust inMarketResearch Relationships." Journal of Marketing 57 (January): 81-101.

Narver, J.C. and Slater S.F., 1990, 'The Effect of a Market Orientation on Business Profitability', Journal of Marketing, 54, pp. 20-35.

Ndubisi, N. O. (2012). Relationship between entrepreneurship, innovation and performance: Comparing small and medium-size enterprises. Journal of Research in Marketing and Entrepreneurship, 14(2), 214-236.

Noble, C. H., Sinha, R. K., \&Kumar, A. (2002). Market orientation and alternative strategic orientations: A longitudinal assessment of performance implications. Journal of Marketing, 66(4), 25-39. 
O'Cass, A. and Ngo, L. V. (2007a)," Market orientation versus innovative culture: two outes to superior brand performance", European Journal of Marketing, Vol. 41, No. 7/8, pp. 868-887

Olavarrieta Sergio, Friedmann Roberto. Market-oriented culture, knowledge- related resources, reputational assets and superior performance: a conceptual framework. J Strat Mark 1999;7:215-28 [December].

Palmatier, R. W., Dant, R. P., \& Grewal, D. (2007). A comparative longitudinal analysis of theoretical perspectives of interorganizational relationship performance. Journal of Marketing, 71, 172-194.

Pass, C., Lowes, B., Pendleton, A., \& Chadwick, L. (1995). Collins Dictionary of Business, 2nd ed. HarperCollins Publishers, Glasgow.

Prahalad, C.K. and Hamel, G. (1990), "The core competence of the corporation", Harvard Business Review, May-June, pp. 79-91.

Roach, D. C. (2011). The impact of product management on SME firm performance. Journal of Research in Marketing and Entrepreneurship, 13(1), 85-104.

Sarah, S., \& Arokiasamy, L. (2009). The Background and Challenges Faced by the Small Medium Enterprises . A Human Resource Development Perspective, 95-102.

Slater, S.F. and Narver, J.C., 1995, 'Market Orientation and the Learning Organization', Journal of Marketing, 59, 3, pp. 63-75.

Slater, S.F. and Narver, J.C. 1994, 'Market Orientation, Customer Value and Superior Performance', Business Horizons, March-April, pp. 22-28.

Sinkula James R. Market information processing and organizational learning. J Mark 1994;58:35-45 [January].

Song, M., Droge, C., Hanvanich, S., \& Calantone, R. (2005). Marketing and technology resource complementarity: An analysis of their interaction effect in two environ- mental contexts. Strategic Management Journal, 26(3), 259-276.

Song, M., Benedetto, A. D., \& Nason, R. W. (2007). Capabilities and financial performance: The moderating effect of strategic type. Journal of the Academy of Marketing Science, 35,18-34.

Song, M., Nason, R.W.,\&Benedetto, A. D. (2008). Distinctive marketing and information technology capabilities and strategic types: A cross national investigation. Journal of International Marketing, 16(1), 4-38.

Ricardo,R.,\&Wade,D.(2001). Corporate Performance Management: How to Build a Better Organization Through Measurement Driven Strategies Alignment. Butterworth Heinemann.

Roach, D. C. (2011). The impact of product management on SME firm performance. Journal of Research in Marketing and Entrepreneurship, 13(1), 85-104.

Urde, M. (1999), "Brand orientation: a mindset for building brands into strategic resources", Journal of Marketing Management, Vol. 15 Nos. 1-3, pp. 117-33.

Vanauken, B. (2002). The brand management checklist. London, N1: Kogan Page.

Vijande, Perez, Gutierrez, R. (2012). Marketing Capabilities Development in Small and Medium Enterprises: Implications for Performance. Journal of CENTRUM Cathedra: The Business and Economics Research Journal, 5(1), $24-42$.

Vorhies, D. W., and Morgan, N. A. (2005). Benchmarking marketing capabilities for sustainable competitive advantage. Journal of Marketing, 69(1), 80-94.

Weerawardena, J., O'Cass, A., 2004. Exploring the characteristics of the market-driven firms and antecedents to sustained competitive advantage. Industrial Marketing Management 33 (5), 419-428.

Weerawardena, J., O'Cass, A. and Julian, C. (2006), "Does industry matter? Examining the role of industry structure and organizational learning in innovation and brand performance", Journal of Business Research, Vol. 59, pp. 37-45.

Wernerfelt, B. (1984): "A resource-based view of the firm", Strategic Management Journal, Vol. 5, pp. 171-180.

Wiklund, J., \& Shepherd, D. 2003. Aspiring for achieving growth: The moderating role of resources and opportunities. Journal of Management Studies, 40:1919-1941

Woodside, A.G., D.P. Sullivan and R.J. Trappey (1999). Assessing Relationships Among Strategic Types, Distinctive Marketing Competencies and Organizational Performance. Journal of Business Research 45: 135 - 146.

Wong, Y. and Merrilees, B. (2005), "A brand orientation typology for SMEs: a case research approach", Journal of Product \& Brand Management, Vol. 14 Nos 2/3, pp. 155-62.

Wong, H.Y., Merrilees, B., 2008. The performance benefits of being brand-oriented. Journal of Product \& Brand Management 17, $372-$ 383.

Zhou, K. Z., Gao, G. Y., Yang, Z., \& Zhou, N. (2005). Developing strategic orientation in China: Antecedents and consequences of market and innovation orien- tations. Journal of Business Research, 58(8), 1049- 1058 